\title{
VALUE OF PHOTOSYNTHESIS IN GROWING MEADOW CLOVER DEPENDING ON TECHNOLOGY ELEMENTS
}

Vitalii Kovalenko $^{1}$, Sergii Kokovikhin ${ }^{2}$, Ella Dobrovolska ${ }^{3}$, Nataliia Korzhenivska ${ }^{3}$, Oleksander Kozak ${ }^{3}$

${ }^{1}$ National University of Life and Environmental Sciences of Ukraine, Ukraine; ${ }^{2}$ Institute of Irrigated Agriculture of NAAS, Ukraine; ${ }^{3}$ State Agrarian and Engineering University in Podilya, Ukraine kovalenko_v@nubip.edu.ua,serg.ac@ukr.net,dakgps@pdatu.edu.ua

\begin{abstract}
The indicator of the net productivity of photosynthesis, which is presented in the work, more fully than the leaf area, reflects the real possibilities of agrobiocenosis for the synthesis of organic matter. The performance of photosynthesis of each individual plant, as well as agrocenosis as a whole, is due to many factors, therefore, it is important to develop a set of measures aimed not only at meeting the needs of plants in moisture and mineral nutrition, but also to promote their functioning. It is established that the net productivity of meadow clover grasslands photosynthesis increases with the leaf surface index of 3.5. At the same time, the achievement of higher indicators is gradually decreasing, regardless of the mineral nutrition variety, levels and plant density. It was also revealed in our research that the highest indicator of net productivity of meadow clover photosynthesis of cultivars Agros-12 and Marusia of the second year of vegetation in the first mowing was recorded without weeding. In the same cutting of meadow clover of the second year of vegetation on a variant with inoculation of seeds and added fertilizers in the norm of N60P60K90 at cultivation of meadow clover sowing the lowest indicator of net productivity of photosynthesis was noted. In the second cutting the indicators of net productivity of photosynthesis were revealed like this: the maximum indicators on the variant without fertilizers and inoculations and the minimum on the variant for cultivation with the introduction of fertilizers in the standard of N60P60K90 and seed treatment with rhizotorphin. It is one of the most important parameters with which the yield level correlates.
\end{abstract}

Keywords: meadow clover, net productivity of photosynthesis, total plant biomass, forage crop.

\section{Introduction}

The specific weather conditions of the last ten years, as well as the increase in the length of the periods of the year, increase in temperature, and the extremely unfavourable wintering conditions confirmed the necessity of strengthening the direction of feed production research. The effectiveness of research in the cultivation of feed is evidenced by the specific results in the selection. In recent years, meadow clover varieties have become widespread: Agros-12 (Nosiv Research Station of Chernihiv Institute of APV UAAS), and Marusia (NSC Institute of Agriculture of NAAS) [1;2].

The aim of the research is to substantiate and develop agrobiological basis for intensification of meadow clover cultivation on the basis of establishment of quantitative parameters of formation and functioning of stable production zones, namely, to investigate the value of photosynthesis in meadow clover cultivation depending on elements of technology [1-4].

Clover is a versatile forage crop. It is readily eaten by all animals, as well as by birds. High-quality hay, haylage, silage, high-protein grass flour, granules and briquettes are prepared from clover; it is used for green fodder. Clover contains a lot of protein, minerals, vitamins. In terms of nutritional value, it is second only to alfalfa. The high protein nutritional value of clover feed is that per 1 feed unit it contains 1.5 times more digestible protein than according to zootechnical standards. Therefore, the use of clover, like alfalfa, allows balancing the carbohydrate feed in terms of protein content [3;5-7].

The green mass contains essential and fatty oils, tannins, glycosides trifolin and isotrifolin, organic acids (p-coumaric, salicylic, ketoglutaric), sitosterol, isoflavones, resins, calcium salts, phosphorus, trace elements, vitamins (ascorbic acid), tocopherol, A, B1, B2, C, D, E). During haymaking, especially natural drying, part of the leaves breaks off, is lost, the fodder value is reduced. When harvesting hay leaves are preserved completely, nutrient losses are minimal. Baldness of meadow clover is $40-44 \%$, creeping - more than $50 \%$ [2; 8-11].

\section{Materials and methods}

In the process of investigation special and general scientific methods were used. In the course of the research a dialectic method and generally scientific methods, such as analysis, synthesis, comparison and generalization were used for collecting, analyzing, information assessing and conclusions making.

Among the special methods such methods were used as: 1) field research - the study of the interaction of the research objects with biotic and abiotic factors in the conditions of the investigated 
area; 2) laboratory research: a) chemical - determination of the chemical composition of plant vegetative mass; b) morpho-physiological - revealing plant biometric parameters, c) physical - disclosing indicators of plant physical quality.

\section{Results and discussion}

The research was based on the establishment of quantitative parameters for the formation and operation of stable production zones, the level of realization in them, depending on weather characteristics and agrotechnical factors, productive potential of the mentioned crops, optimization of crop placement and development, high energy payback, conditions of environment of technologies of cultivation of perennial legumes due to improvement and complex combination of basic agrotechnical techniques in a complete technological cycle.

With growing varieties of clover the height of plants, with variants without the use of mineral fertilizers, in the first mowing was 63.4-63.8 cm, in the second $24.9-28.2 \mathrm{~cm}$. In the second mowing the height was $24.9 \mathrm{~cm}$ for the Marusia variety and $28.2 \mathrm{~cm}$ for the Agros-12 variety. The use of phosphoruspotassium fertilizers (P60K90) in combination with inoculation contributed to an increase in the height of clover varieties in the first mowing up to 65.8-67 and in the second one up to 32.6-33.6 cm. In case of complete mineral fertilization in the standard N60P60K90, with the conduction of pre-inoculation of the seed, a yield of green mass of clover was obtained at the level of 38.71-39.39 th ha ${ }^{-1}$. The output of the dry matter was 7.47-7.60 th ha ${ }^{-1}$, respectively.

Net productivity of photosynthesis reflects the increase in total plant biomass over a period of time relative to the average leaf area for the same period and is expressed in $\mathrm{g} \cdot \mathrm{day}^{-1} \cdot \mathrm{m}^{-2}$. The photosynthetic sowing potential is calculated based on the sum of the leaf surface area per hectare of sowing per day during the entire growing season.

Taking into account these indicators the efficiency of photosynthesis is characterized.

During the vegetation period two slopes of the leaf-stem mass of meadow clover were obtained. The leaf-stem mass of meadow clover for green fodder was collected when it reached the phase of the beginning of flowering. The first mowing was carried out 93 days after sowing (July 28), while the second mowing was formed 50 days and was collected on September 15.

It is established that the meadow clover grass net productivity of photosynthesis stands increases by the leaf surface index of 3.5. At the same time, the achievement of higher indicators is gradually reduced, regardless of the variety, levels of mineral nutrition and plant density $[1 ; 2 ; 4 ; 5]$.

To obtain high and stable yields, it is very important to have not only a strong, but also a highly productive photosynthetic apparatus, the indicator of which is the net productivity of photosynthesis, which characterizes the increase in dry matter per unit area per unit time.

It was investigated that the net average productivity of photosynthesis in productive crops reaches $5-6 \mathrm{~g} \cdot \mathrm{m}^{-2}$, the maximum $-10-14 \mathrm{~g} \cdot \mathrm{m}^{-2}$ per day. The net productivity of photosynthesis in clover is relatively low - on average during the growing season about $3-4 \mathrm{~g} \cdot \mathrm{m}^{-2}$ per day.

Analyzing how the indicators of pure productivity of various varieties of meadow clover photosynthesis and the levels of mineral nutrition affect, the highest net productivity of photosynthesis (3.39 $\mathrm{g} \cdot \mathrm{m}^{-2}$ per day) of meadowclover Marusia in the second year of vegetation during the growing season was recorded for the variant without processing the seeds with rhizotorfin and without carrying away mineral fertilizers.

In the same mowing of meadow clover Marusia of the second year of vegetation on a variant with inoculation of seeds and the applied fertilizers in the norm N60P60K90 at cultivation of clover (Fig. 1).

In the second mowing, the indicators of the net productivity of photosynthesis of Marusia variety appeared in the following way: the maximum indices for the variant without fertilizers and inoculation are $3.51 \mathrm{~g} \cdot \mathrm{m}^{-2}$ per day and the minimum $-3.25 \mathrm{~g} \cdot \mathrm{m}^{-2}$ per day for the variant for growing with the removal of fertilizers in N60P60K90 standard and processing of seeds with rhizotorfin.

Similar indicators, but with insignificant deviations, were found on the thickness of grass of meadow clover of the second year of vegetation of Agros-12 variety.

Studies have shown that in the control and in the first cut there were the highest rates of net productivity of photosynthesis - respectively 3.31 for the variant without processing seeds with 
rhizotorfin and without adding mineral fertilizers and $3.11 \mathrm{~g} \cdot \mathrm{m}^{-2}$ per day for the variant with inoculating seeds and applying fertilizer in the norm of N60P60K90, in the second one 3.49-3.21 respectively.

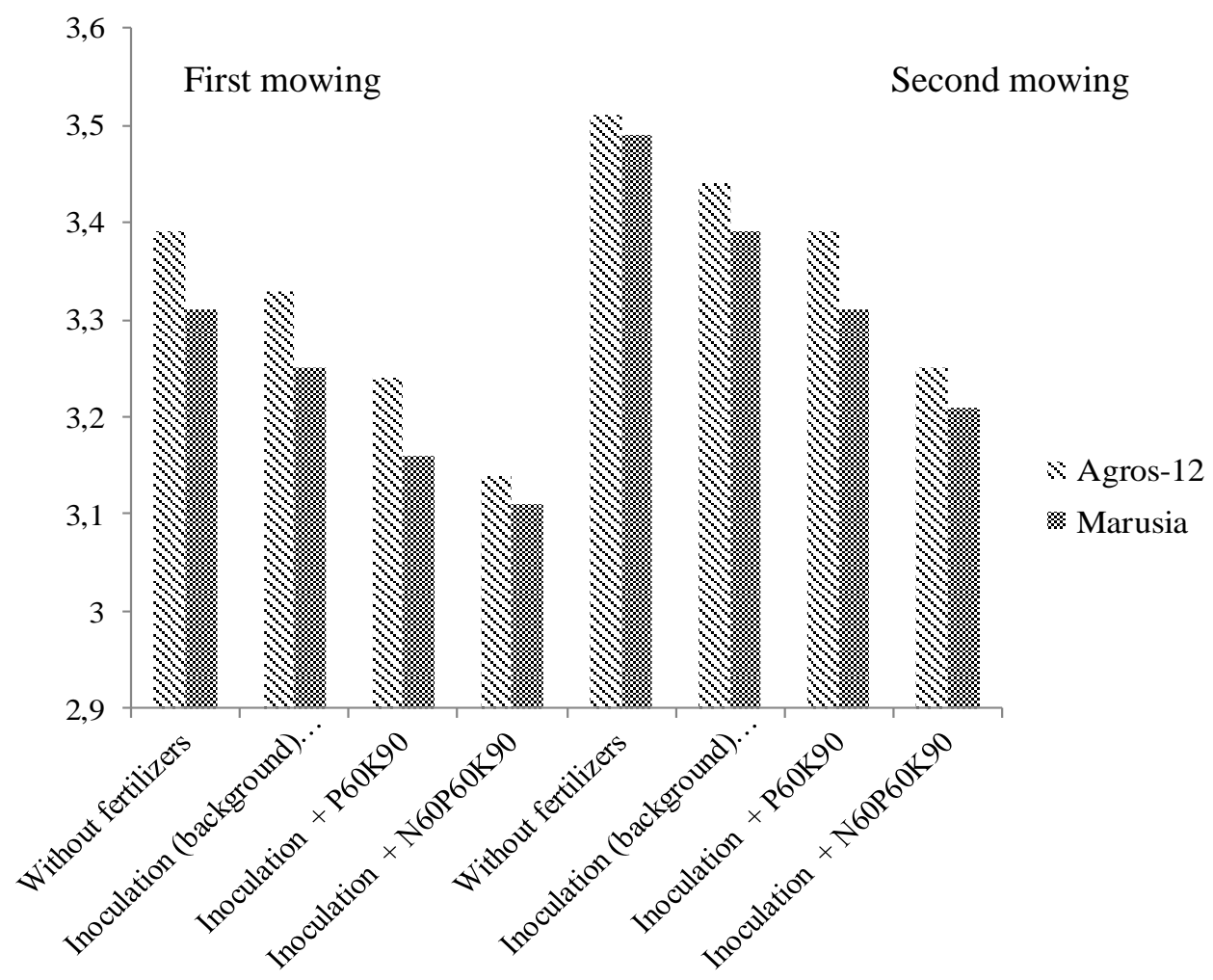

Fig. 1. Net productivity of photosynthesis of meadow clover plants of the second year of vegetation, depending on the method of cultivation, $\mathrm{g} \cdot \mathbf{m}^{-2}$ per day

The lowest value of pure photosynthesis productivity for Agros-12 variety on average in the first and second mowing was recorded for the variant with the standard of N60P60K90 and inoculation of seeds.

In addition, it was established that for the second year of grass meadow clover of both varieties' use, the maximum indicators of net productivity of plant photosynthesis appeared on the variants under normal cultivation, without the introduction of fertilizers and inoculation.

\section{Results and discussion}

The use of N60P60K90 significantly changed the size of the leaf apparatus in comparison with the control. Thus, when the norm was brought to $90 \mathrm{~kg} \cdot \mathrm{ha}^{-1}$, the leaf area increased to 56-60 thousand $\mathrm{m}^{2} \cdot \mathrm{ha}^{-1}$, which in turn caused a decrease in net productivity of photosynthesis in these variants. This is due to the fact that on a higher background of nutrition with the development of a strong leaf surface, the leaves overshadow each other, the lighting conditions deteriorate, resulting in a decrease in the intensity of photosynthesis per unit leaf surface.

In case of growing clover should use the variety Agros-12 with the treatment of seeds with inoculants and application of mineral fertilizers norm P60K90.

In addition to high forage productivity and protein collection, the value of meadow clover determines its ability to meet its own needs in nitrogen nutrition due to symbiosis with nodule bacteria, and high nitrogen content in root residues allows to increase its amount in the soil, which turns clover into a productive predecessor.

The prospect of development of the forest-steppe zone is the conduct of highly efficient animal husbandry, first of all, dairy and meat cattle. To increase production, improve the quality and reduce the 
cost of feed, it is necessary to introduce and master special feed crop rotations with maximum saturation of legumes.

\section{Conclusions}

The amount of solar radiation that penetrates the grass depends on the density of crops and baldness of plants. Both the lack and excess of radiation adversely affect the formation and quantity of the crop. Its high intensity causes the decomposition of chlorophyll, as a result of which the leaves turn yellow and fall off. Calculations have shown that the highest efficiency of photosynthetically active radiation with the existing and optimized cultivation technology in the range of 1.63-2.87\% was observed when growing alfalfa. Correlation-regression analysis allowed establishing a high potential level of net productivity of photosynthesis with maximum use of natural and technological factors. The mentioned figure for alfalfa can be $3.71 \%$, clover and sainfoin $-3.28-3.52 \%$.

\section{References}

[1] Demydas G.I. et al. Bagatorichni bobovi travy yak osnova pryrodnoi intensyfikatsii kormovyrobnytstva (Perennial legumes as a basis for natural intensification of fodder production). Kyiv: Tsentr uchbovoi literatury, Center for educational literature, 2013. 322 p. (In Ukrainian)

[2] Kovalenko V.P. Optymizatsiia udobrennia i yogo rol u formuvanni produktyvnosti fitomasy sorti koniushyny luchnoi (Optimization of fertilizer and its role in the formation of phytomass productivity of meadow clover varieties). NaukovidopovidiNUBiPUkrainy (Scientific reports of NULES of Ukraine). 2017. No. 1(65). [online] [21.03.2021] Available at: http://journals.nubip.edu.ua/index.php/Dopovidi/ article/view/ 8118/7760. (In Russian)

[3] Kovalenko V.P., Kokovikhin S.V., Galchenko N.M. Naukovo-praktychni zasady vyroshchuvannia bagatorichnykh bobovykh trav v umovakh Lisostepu i Stepu Ukrainy: monografiia (Scientific and practical principles of growing perennial legumes in the Forest-steppe and Steppe of Ukraine: monograph). Kherson: Ailant, 2019. 208 p. (In Russian)

[4] Zihchenko B. S. et al. Liutserna i koniushyna (Alfalfa and clover). Kyiv: Urozhai, 1989. 232 p. (In Russian)

[5] Korchak M., Yermakov S., Maisus V. etc. Problems of field contamination when growing energy corn as monoculture. Proceedings of 6 th International Conference - Renewable Energy Sources, vol. 154, E3S Web of Conferences. 2020. pp. 01009 DOI: 10.1051/e3sconf/202015401009

[6] Andrushchak V. et al. Professionalnoe proizvodstvo: senazh, silos, seno (Professional production: haylage, silage, hay). Kyiv: Izdatelskiidom "Zerno" (Zerno Publishing House), 2012. 168 p. (In Russian)

[7] Tryhuba A, Hutsol T, Tryhuba I etc. Risk Assessment of Investments in Projects of Production of Raw Materials for Bioethanol. Processes. 2021; 9(1):12. DOI: 10.3390/pr9010012

[8] Yarygina N. Ya. Vplyvdobryv, unesenykh v sivozmini, na vmist elementiv zhyvlennia v grunti, urozhai ta yakist sina koniushyny (Influence of fertilizers applied in crop rotation on the content of nutrients in the soil, yield and quality of clover hay). Scientific Herald of National University of Life and Environmental Sciences of Ukraine. Issue 195. Part 1. pp. 107-112. (In Ukrainian)

[9] Yarygina N. Ya., Mazurkevych L. I. Vplyv tryvalogo vykorystannia dobryv u sivozmini na biologichnu fiksatsiiu azotu koniushynoiu: bibliografiia (Influence of long-term use of fertilizers in crop rotation on biological nitrogen fixation by clover: bibliography). Scientific Herald of National Agrarian University. Kyiv, 2008. Issue 129. pp. 265-268. (In Ukrainian)

[10] Ivanyshyn V., Yermakov S., Ishchenko T. etc. Calculation algorithm for the dynamic coefficient of vibro-viscosity and other properties of energy willow cuttings movement in terms of their unloading from the tanker. Proceedings of 6 th International Conference - Renewable Energy Sources, vol. 154, E3S Web of Conferences. 2020. pp. 04005. https://doi:10.1051/e3sconf/202015404005

[11] Tryhuba A., Hutsol T., Glowacki S. etc. Forecasting Quantitative Risk Indicators of Investors in Projects of Biohydrogen Production from Agricultural Raw Materials. Processes 2021, 9, 258. DOI: $10.3390 /$ pr9020258 